\title{
Geographical Origin Characterization of Slovenian Organic Garlic Using Stable Isotope and Elemental Composition Analyses
}

\author{
Anja Mahne Opatić, ${ }^{1,2}$ Marijan Nečemer, ${ }^{4}$ David Kocman ${ }^{1}$ and Sonja Lojen ${ }^{1,3}$ \\ ${ }^{1}$ Department of Environmental Sciences, “Jožef Stefan” Institute, Jamova cesta 39, Ljubljana, Slovenia_ \\ ${ }^{2}$ Jožef Stefan International Postgraduate School, Jamova cesta 39, Ljubljana, Slovenia \\ ${ }^{3}$ Faculty of Environmental Science, University of Nova Gorica, Vipavska 13, Nova Gorica, Slovenia \\ ${ }^{4}$ Department of Low and Medium Energy Physics, "Jožef Stefan” Institute, Jamova cesta 39, Ljubljana, Slovenia \\ *Corresponding author: E-mail: anja.mahne00@gmail.com \\ Tel: +038631873994
}

Received: 25-04-2017

\begin{abstract}
In the present research, the applicability of stable isotope $\left(\delta^{13} \mathrm{C}, \delta^{15} \mathrm{~N}, \delta^{34} \mathrm{~S}, \delta^{18} \mathrm{O}\right)$ and multi-element $(\mathrm{P}, \mathrm{S}, \mathrm{Cl}, \mathrm{K}, \mathrm{Ca}, \mathrm{Zn}, \mathrm{Br}$, $\mathrm{Rb}, \mathrm{Sr}$ ) data for determining the geographical origin of garlic (Allium sativum L.) at the scale of Slovenia was examined. Slovenia is a rather small country $\left(20273 \mathrm{~km}^{2}\right)$ with significant geological and biological diversity. Garlic, valued for its medicinal properties, was collected from Slovenian farms with certified organic production and analyzed by elemental analyzer isotope ratio mass spectrometry combined with energy dispersive $\mathrm{X}$ - ray fluorescence spectrometry. Multivariate discriminant analysis (DA) revealed a distinction between four Slovenian macro-regions: the Alpine, Dinaric, Mediterranean and Pannonian. The model was validated through a leave- $10 \%, 20 \%$ and $25 \%$ out cross validation. The overall success rate of correctly reclassified samples was $77 \%$ (on average), indicating that the model and the proposed methodology could be a promising tool for rapid, inexpensive and robust screening to control the provenance of garlic samples.
\end{abstract}

Keywords: Food traceability, Garlic, Geographical origin, Stable isotopes, Elemental composition, Slovenia

\section{Introduction}

Garlic (Allium sativum L.), a bulb vegetable widely used in global cuisine, is one of the most investigated food products. It contains approximately $65 \%$ water, $28 \%$ carbohydrates, $2 \%$ proteins, $1.2 \%$ free amino acids and $1.5 \%$ fiber. A further $2.3 \%$ is comprised of organosulfur compounds, which give garlic its characteristic pungent taste and flavor. These compounds are strongly related to garlic's beneficial effects on health, ${ }^{1}$ exhibiting antioxidant, antimicrobial, anticarcinogenic and antimutagenic activities as well as containing protective medicinal properties against cardiovascular and respiratory diseases. ${ }^{1,2}$

In recent years, proof of provenance has played an increasingly significant role in food safety and quality surveillance programmes. It also affects consumers' rights in accordance with national legislation, international standards and guidelines. Thus, geographical origin determi- nation has become another fundamental factor used for evaluating the quality of a product. ${ }^{3}$ In Slovenia, the quality of garlic is currently defined by the Rules on the Quality of Vegetables. ${ }^{4}$ At larger scale, in Europe, Commission Regulation (EC) No. 2288/97 lays down the marketing standards for garlic. ${ }^{5}$ These rules concern the visual appearance of vegetables (size, shape, firmness, cleanliness etc...), packaging and labeling, including the declaration of origin of produce. Nevertheless, rapid, reliable, robust and inexpensive screening methods are still necessary in order to ensure the geographical authenticity and traceability of food products and in addition, the main goal of research in this field has been lately focused on defining the parameters and providing appropriate analytical tools. One of the important techniques, where the scope of geographical assignment of food products can be remarkably extended, relies on a combination of isotopic and elemen- 
tal fingerprinting. An important prerequisite is the availability of suitable databases, based on a large number of authentic samples. Moreover, basic knowledge on stable isotope fractionation effects in nature also needs to be increased. ${ }^{6}$ For garlic, no databank for tracing its origin at national, continental or global scale has been set up yet, in spite of global utilization of garlic as a condiment in cuisine or for medicinal purposes. ${ }^{7}$

Many authors have attempted to determine the geographical origin of different cereal grains, ${ }^{8-11}$ Chinese teas ${ }^{12}$ and honey ${ }^{13}$ using only stable isotopes of light elements. Samples classification into groups according their geographical origin was relatively successful, indicating that better classification could be achieved by applying not only stable isotope ratios of one or two light elements, but by using multielement stable isotope ratio data. Moreover, the use of stable isotope data in combination with multi-elemental analysis can provide even better discrimination in the case of apple juices, ${ }^{14}$ teas, ${ }^{15}$ tomatoes ${ }^{16}$ wines ${ }^{17}$ and honey. ${ }^{18}$ In spite of this, a combination of multielement stable isotopes and multi-element fingerprinting has been rarely used, especially for tracing the geographical origin of vegetables. There has been scarce research on determining the geographical origin of garlic. Smith $(2005)^{19}$ proposed trace metal profiling using high-resolution inductively coupled plasma mass spectrometry in order to determine the country of origin of garlic, whilst to authors very best knowledge there appears to be very little literature data published applying stable isotope ratios or their combination with elemental composition data, e.g. Feher et al., (2017). ${ }^{20}$

The popularity of garlic in Slovenia is increasing extremely. According to the Statistical office of Republic of Slovenia total production of garlic in Slovenia in 2015 was
$980 \mathrm{t}$, hereof $478 \mathrm{t}$ for market production..$^{21}$ This was 3 times higher for total production and 35-40 times higher for market production in comparison to 10 years ago. In ten years (i.e., 2005-2015) the garlic import from other countries has decreased for around $20 \%$, and amounted to $1296 \mathrm{t}$ in $2015 .{ }^{22}$ Slovenia is a small country $\left(20273 \mathrm{~km}^{2}\right)$ characterized by rich geological, climatological and biological diversity. It is situated between the Alps, the Dinaric Mountains, the Pannonian Basin and the Mediterranean Sea, making it ideal for this study. Our primary aim was to examine the possibility of using stable isotope ratio, multielement analyses, and chemometry (specifically, multivariate discriminant analysis (DA)) for characterizing and classifying organically grown Slovenian garlic according to the geographical macro-region in which it was cultivated (Alpine, Dinaric, Pannonian, or Mediterranean). The data gathering at the scale of Slovenia has commenced within the framework of the project "ISO-FOOD- ERA chair for isotope techniques in food quality, safety and traceability" funded by the EU. Furthermore, it is also expected that our findings will initiate the creation of a national database as the proposed methodology could be a promising tool for fast and cheap screening purposes which would allow for seamless implementation into existing food regulations and trade agreements.

\section{Materials and Methods}

\section{1. Sampling}

Samples were collected in autumn 2014 and 2015 from several Slovenian certified organic farms in order to ensure authenticity, traceability and equivalent production regimes. In total, 38 samples of garlic from four different Slovenian macro-regions (Fig. 1) were obtained.

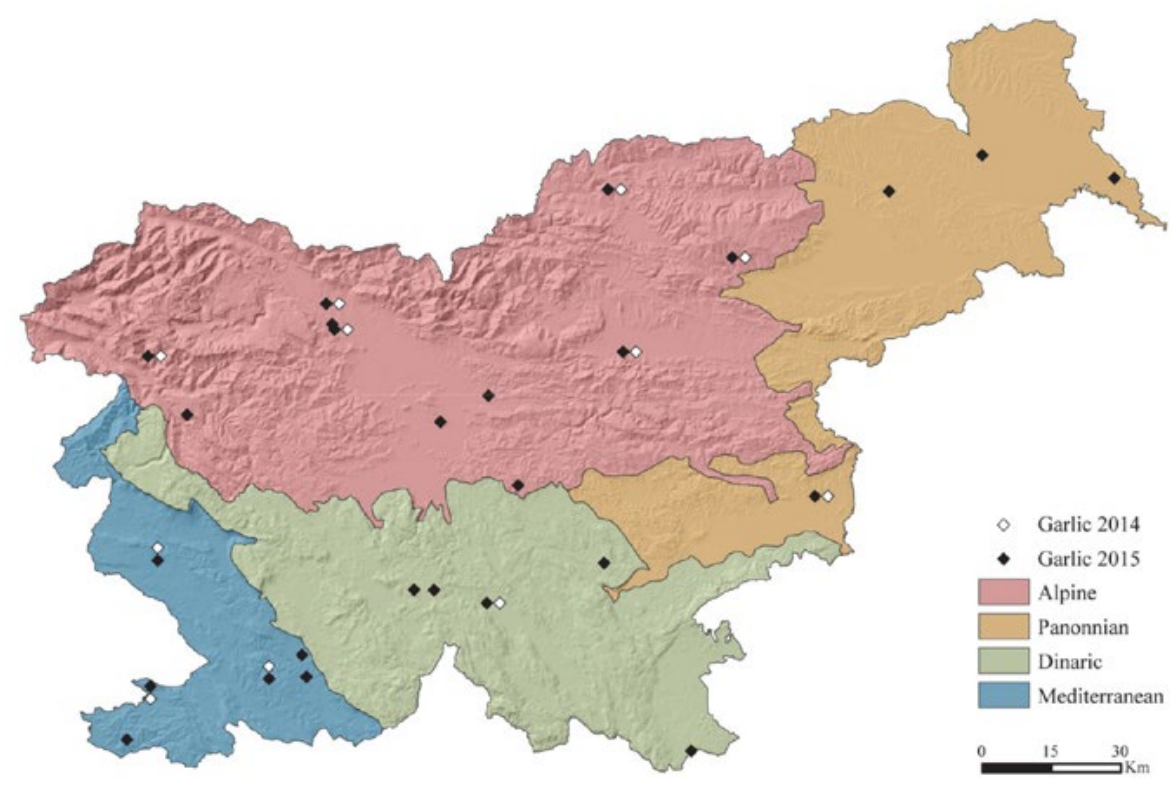

Fig. 1. Regionalization of Slovenia into four macro-regions ${ }^{23}$ with sampling sites and years of garlic samples 


\section{2. Stable Isotope Analysis}

Samples for simultaneous carbon, nitrogen and sulfur isotope ratio analysis were dried to constant weight in an oven at $60{ }^{\circ} \mathrm{C}$. The dried samples were then homogenized and ground to a fine powder using a mortar. A known weight $(10 \mathrm{mg})$ of garlic powder was folded and compressed in a tin capsule and introduced into the autosampler. Analysis was carried out using an Elementar vario PYRO cube elemental analyser (OH/CNS Pyrolyser/ Elemental Analyser) linked to an IsoPrime100 continuous flow isotope ratio mass spectrometer (IsoPrime, Cheadle, Hulme, UK). Each sample was analyzed in three repetitions. The difference between the replicates for any of the elements did not exceed $0.2 \%$.

For oxygen stable isotope analysis, liquid samples were obtained by squeezing fresh garlic through a gauze. Isotopic ratios were then measured after equilibration (40 ${ }^{\circ} \mathrm{C}$, 6h) with $5 \% \mathrm{CO}_{2}+\mathrm{He}$ mixture. Analysis was performed using an IsoPrime100 isotope ratio mass spectrometer and MultiFlow preparation system (IsoPrime, Cheadle, UK) according to the ENV 12141:1996. ${ }^{24}$

The stable isotope compositions are reported according to the IUPAC guidelines ${ }^{25,26}$ as relative differences in the isotope ratios (isotope-delta values), as seen in Equation $(1)^{25}$ :

$$
\delta^{i / j} \mathrm{E}=\frac{{ }^{i / j} R_{\mathrm{p}}-i / j}{{ }_{\text {Ref }}}
$$

The superscripts $i$ and $j$ denote the higher and lower atomic masses of the analysed element $\mathrm{E}$, and $R_{P}$ and $R_{\text {Ref }}$ denote the heavy-to-light isotope ratios of the element $\mathrm{E}$ in the analysed sample and the reported reference material, respectively. A short-hand notation for elements with only two relevant stable isotopes is used in the text, i.e., $\delta^{13} \mathrm{C}, \delta^{15} \mathrm{~N}$, and the $\delta^{34} \mathrm{~S}$; the $\delta$ values are expressed in per mil (\%) relative to standards. The $\delta^{13} \mathrm{C}$ values are expressed relative to VPDB (Vienna Peedee belemnite) on a scale normalized by assigning consensus values of $-46.6 \%$ to L-SVEC lithium carbonate and $+1.95 \%$ o to NBS 19 calcium carbonate. The $\delta^{18} \mathrm{O}$ values of water are expressed relative to the VSMOW2 (Vienna Standard Mean Ocean Water 2), $\delta^{34} S$ relative to the VCDT (Vienna Canyon Diablo Troilite), and $\delta^{15} \mathrm{~N}$ relative to Air (atmospheric $\mathrm{N}_{2}$ ). By definition, the $\delta$ value of the reporting standards is $0 \%$.

For $\delta^{13} \mathrm{C}$ and $\delta^{15} \mathrm{~N}$ measurements, working standards were used, calibrated versus USGS40 (L-glutamic acid; certified $\delta^{13} \mathrm{C}_{\mathrm{VPDB}}$ value $-26.39 \pm 0.04 \%$; recommended $\delta^{15} \mathrm{~N}$ value $-4.5 \pm 0.1 \%$ ), USGS41 (L-glutamic acid; certified $\delta^{13} \mathrm{C}_{\mathrm{VPDB}}$ value $+37.63 \pm 0.05 \%$; recommended $\delta^{15} \mathrm{~N}_{\text {Air }}$ value $+47.6 \pm 0.2 \%$ ), IAEA-CH- 6 (sucrose with certified $\delta^{13} \mathrm{C}$ value $-10.45 \pm 0.03 \%$ ), IAEA-N-1 (ammonium sulfate with certified $\delta^{15} \mathrm{~N}_{\text {Air }}$ value $+0.4 \pm 0.2 \%$ ) international reference materials, and IAEA-SO-5 (barium sulfate with recommended $\delta^{34} \mathrm{~S}+0.5 \pm 0.2 \%$ ) reference material for sulfur. The accuracies of the $\delta^{13} \mathrm{C}, \delta^{15} \mathrm{~N}$, and $\delta^{34} \mathrm{~S}$ analyses were monitored with commercially available isotope standards (Sercon) with recommended $\delta^{13} \mathrm{C}$ and $\delta^{15} \mathrm{~N}$ values, and informative $\delta^{34} \mathrm{~S}$ values: Wheat Flour Standard Organic Analytical Standard (OAS; $-27.21 \pm 0.13 \%$; +2.85 $\pm 0.17 \%$; $-1.42 \pm 0.80 \%$ or $\delta^{13} \mathrm{C}, \delta^{15} \mathrm{~N}$ and $\delta^{34} \mathrm{~S}$, respectively), Sorghum Flour Standard OAS ( $-13.68 \pm 0.19 \%$; +1.58 $\pm 0.15 \%$; $+10.11 \pm 1.00 \%$ ) and Protein (Casein) Standard OAS $(-26.98 \pm 0.13 \%$; $+5.94 \pm 0.08 \%$; $+6.32 \pm 0.80 \%$ ). All these values were certified by the Elemental Microanalysis Ltd.

The measured $\delta^{18} \mathrm{O}$ values were recalculated using the in-house reference materials (distilled seawater with $\delta^{18} \mathrm{O}$ value $+0.34 \pm 0.07 \%$, MilliQ water with $\delta^{18} \mathrm{O}$ value $-9.12 \pm 0.07 \%$ and snow with $\delta^{18} \mathrm{O}$ value -19.73 $\pm 0.09 \%$ ). All these working standards were calibrated vs. the IAEA international reference material VSMOW2 with recommended $\delta^{18} \mathrm{O}_{\text {VSMOw }}$ value $0 \pm 0.02 \%$ and Greenland Ice-Sheet Precipitation (GISP; certified $\delta^{18} \mathrm{O}_{\text {vSmow }}-24.76$ $\pm 0.09 \%$ ). Reproducibility of the measurements was $\pm 0.1 \%$ or $\delta^{18} \mathrm{O}, \pm 0.2 \%$ for $\delta^{13} \mathrm{C}$ and $\pm 0.3 \%$ o for $\delta^{15} \mathrm{~N}$ and $\delta^{34} S$.

\section{3. Elemental Analysis}

Multielement determination of macro ( $\mathrm{P}, \mathrm{S}, \mathrm{Cl}, \mathrm{K}$, $\mathrm{Ca}$ ) and micro elemental ( $\mathrm{Zn}, \mathrm{Br}, \mathrm{Rb}, \mathrm{Sr}$ ) content was performed in single measurement using non-destructive energy dispersive X-ray fluorescence spectrometry. Pellets were prepared from 0.5 to $1.0 \mathrm{~g}$ of powdered sample material using a pellet die and hydraulic press. For excitation, the disc radioisotope excitation source of $\mathrm{Fe}-55(25 \mathrm{mCi})$ and Cd-109 (20 mCi) from Eckert and Ziegler were used. The emitted fluorescence radiation was measured using an energy dispersive X-ray fluorescence spectrometer consisting of a $\mathrm{Si}(\mathrm{Li})$ detector (Canberra), a spectroscopy amplifier (Canberra M2024), analogue-to-digital converter (Canberra M8075) and PC-based multichannel analyser (S-100 Canberra). The spectrometer was equipped with a vacuum chamber (Fe-55) for measuring light elements $\mathrm{P}-\mathrm{Cl}$. The energy resolution of the spectrometer was 175 $\mathrm{eV}$ at $5.9 \mathrm{keV}$. The complex X-ray spectra were analyzed using AXIL spectral analysis software. Quantification was then performed utilizing the Quantitative Analysis of Environmental Samples (QAES) software, developed in our laboratory. ${ }^{27,28}$ The estimated analysis uncertainty was $5 \%$ to $10 \%$. The accuracy of the data was checked using the National Institute of Standards and Technology 1573a reference material (tomato leaves).

\section{4. Statistical Analysis}

Statistical calculations were carried out using the XL-STAT software package (Addinsoft, New York, USA). Simple statistics included analysis of variance by ANOVA with Duncan's tests for comparison of means for normally distributed data, and Kruskal-Wallis one-way analysis of 
variance by ranks (Kruskal-Wallis test) for not normally distributed data in order to reveal statistically significant differences, whilst multivariate DA was used for determination of key factors responsible for discrimination of four Slovenian geographical macro-regions.

\section{Results and Discussion}

\section{1. Garlic}

In Table 1 means and standard deviations of the stable isotope and elemental composition of the 38 garlic samples according to their given macro-region origin are reported, whilst Table 2 gives means, standard deviations and ranges (minimum- maximum) of the stable isotope and elemental composition of the 38 garlic samples, irrespective of geographical origin. The data of $\delta^{15} \mathrm{~N}, \delta^{18} \mathrm{O}, \delta^{34} \mathrm{~S}, \mathrm{P}, \mathrm{K}$ and $\mathrm{Zn}$ were normally distributed and their variances were homoscedastic, while the data of $\delta^{13} \mathrm{C}, \mathrm{S}, \mathrm{Cl}, \mathrm{Ca}$, $\mathrm{Br}, \mathrm{Rb}, \mathrm{Sr}$ and $\mathrm{Si}$ were not normally distributed. According to ANOVA test three parameters $\left(\delta^{18} \mathrm{O}, \mathrm{P}, \mathrm{K}\right)$ were statistically significant $(\mathrm{p}<0.05)$ for discriminating between the four Slovenian macro-regions. Additionally, the Kruskal- Wallis test revealed that only $\delta^{13} \mathrm{C}$ is statistically significant for determining the origin of the garlic samples.

\section{2. Stable Isotopes}

We emphasize that only statistically significant parameters are described below. In this regard, the post-hoc Duncan test revealed that it is possible to differentiate the Mediterranean region from all the other regions on the basis of $\delta^{18} \mathrm{O}$ values. The lowest $\delta^{18} \mathrm{O}$ values were measured in garlic samples from the Dinaric region (average $\delta^{18} \mathrm{O}=-2.6 \%$ ), whilst the highest $\delta^{18} \mathrm{O}$ values were found in samples from the Mediterranean region (average $\delta^{18} \mathrm{O}=-0.8 \%$ ). The Alpine and Pannonian regions fell in between with average values of $\delta^{18} \mathrm{O}=-2.1 \% 0$ and $\delta^{18} \mathrm{O}=$ $-1.9 \%$, respectively. The xylem sap of terrestrial plants reflects the integrated isotopic compositons of the water sources, since the water is absorbed through the root system with no isotopic fractionation during uptake. After that, transpiration through the leaf stomata occurs, leading to enrichment of $\delta^{18} \mathrm{O}$ in the leaf water. ${ }^{29}$ The distribution trends of $\delta^{18} \mathrm{O}$ values in garlic samples is similar to that observed in Slovenian groundwater, ${ }^{30}$ when considering the $\delta^{18} \mathrm{O}$ content of groundwater in the Mediterranean re-

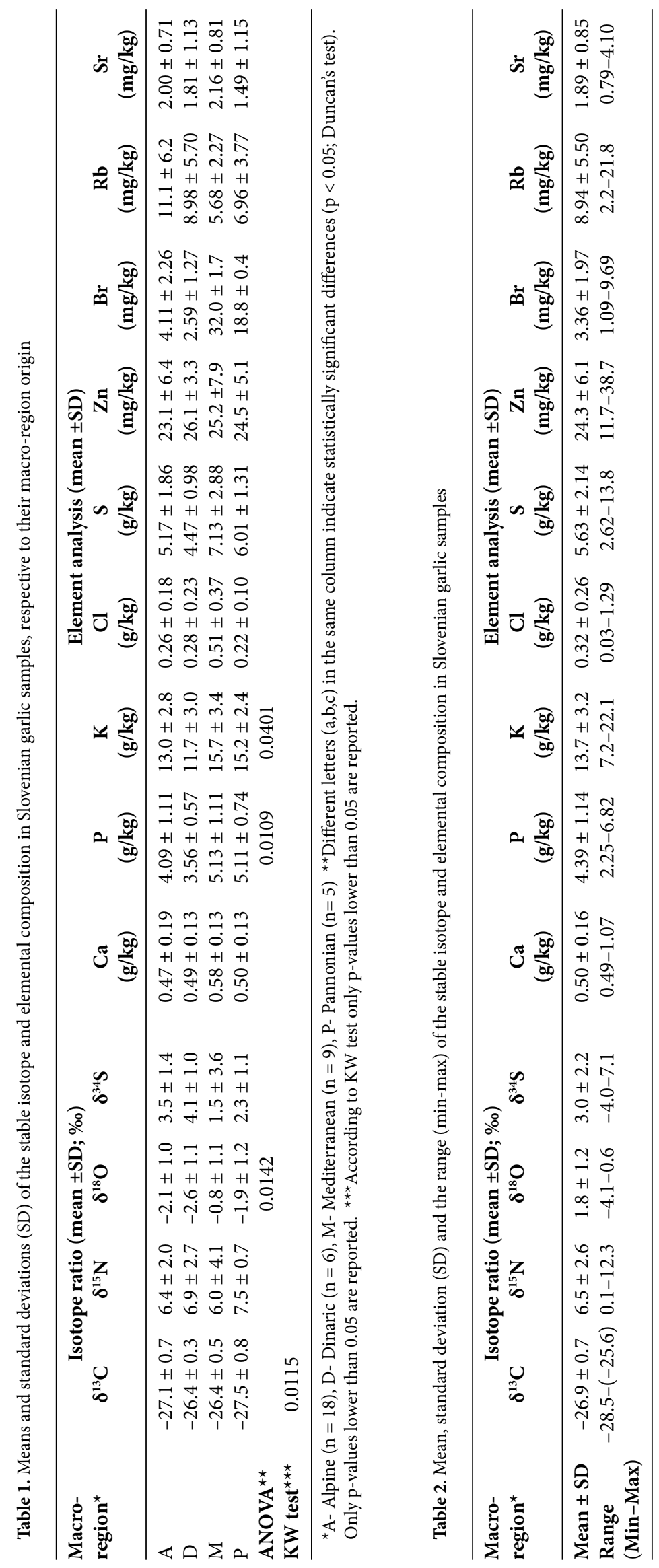




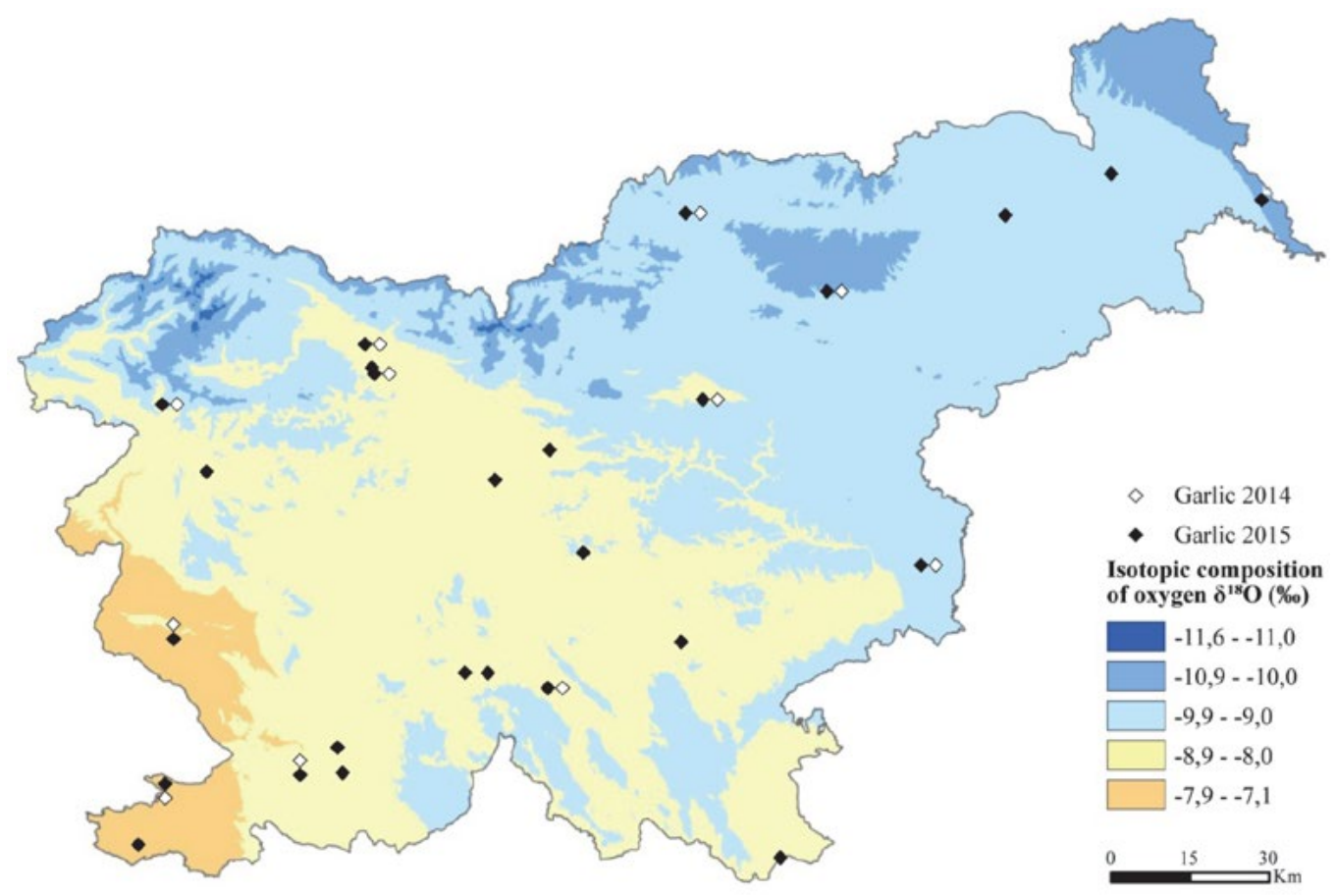

Fig. 2. Assessment of isotopic composition of $\delta^{18} \mathrm{O}$ in groundwater in Slovenia (multiple linear regression method) ${ }^{30}$ and sample sites for garlic samples

gion and in garlic samples from this region (Fig. 2). The lowest values in groundwater were detected in several Alpine areas, which is not in accordance with our results obtained from garlic. Here, it should be taken into account that the distribution of $\delta^{18} \mathrm{O}$ in precipitation across Slovenia is almost identical to that in groundwater, however, there is no databank for the isotopic composition of precipitation in Slovenia yet. However, our results are in agreement with the literature data, ${ }^{8,14,31-32}$ which indicate that the coastal regions have higher $\delta^{18} \mathrm{O}$ values due to a relatively warm and dry climate (temperature and amount effect, respectively). The factors that most influence the fractionation of $\delta^{18} \mathrm{O}$ are distance from the sea (continental effect) and altitude and latitude characteristics. ${ }^{31,32}$

\section{3. Elements}

The elements measured by energy dispersive X-ray fluorescence spectroscopy can be divided into two groups: macro and microelements. In total, 9 elements were determined, 5 macro- (K, P, S, Ca, Cl) and 4 microelements ( $\mathrm{Zn}$, $\mathrm{Rb}, \mathrm{Br}, \mathrm{Sr}$ ). We emphasize that only the stastistically significant parameters are described below and results are depicted as $\mathrm{g} / \mathrm{kg}$ of dry matter (DM). Based on average values of $\mathrm{P}$, the Mediterranean region $(5.13 \mathrm{~g} / \mathrm{kg}$ ) was distinguishable from both the Alpine $(4.09 \mathrm{~g} / \mathrm{kg})$ and Dinaric regions $(3.56 \mathrm{~g} / \mathrm{kg})$, but not from the Pannonian $(5.11 \mathrm{~g} / \mathrm{kg})$. Further, based on the average $\mathrm{K}$ values, the Mediterranean region $(15.7 \mathrm{~g} / \mathrm{kg})$ was found to be statistically different from both the Alpine $(13.0 \mathrm{~g} / \mathrm{kg})$ and Dinaric $(11.7 \mathrm{~g} / \mathrm{kg})$ regions, but not from the Pannonian $(15.2 \mathrm{~g} / \mathrm{kg})$. It was also not possible to discriminate the Pannonian region from both the Dinaric and Alpine regions.

In order to easier compare the elemental content of Slovenian garlic with literature data, average values can be defined, irrespective to the geographical origin (Table 2). Our results reveal differences in comparison with the literature data. For example, Chekki et al. (2014) ${ }^{33}$ reported that concentration of $\mathrm{P}$ in Tunisian garlic was $0.14 \mathrm{~g} / \mathrm{kg}$, which is lower than in Slovenian garlic $(4.39 \mathrm{~g} / \mathrm{kg})$, while the opposite is true for Indian $(4.60 \mathrm{~g} / \mathrm{kg})$ and Turkish $(6.01 \mathrm{~g} / \mathrm{kg})$ garlic. Contents of K $(16.68 \mathrm{~g} / \mathrm{kg}), \mathrm{P}(4.78 \mathrm{~g} /$ $\mathrm{kg}), \mathrm{Ca}(0.69 \mathrm{~g} / \mathrm{kg})$ and $\mathrm{Zn}(66 \mathrm{mg} / \mathrm{kg})$ in Nigerian garlic were reported by Akinwande and Olatunde (2015). ${ }^{34}$ These concentrations are found to be higher than ours. A similar range of concentrations was reported by Gonzálvez A et al. (2008). ${ }^{35}$ The present data shows the heterogeneity of the results and the geographical and/or environmental influences on mineral content of garlic, which makes mineral profiling a possible tool for determining the geographical origin of internationally produced garlic.

\section{4. Results of Multivariate Discriminant Analysis (DA)}

Fig. 3(a) shows discriminant score plots of Slovenian garlic samples in order to verify the possibility to differentiate samples according to the geographical origin using the combination of stable isotope and multi-elemental composition data, while in Fig. 3(b) plot of correlations between initial variables and discriminant factors (F1, F2) is seen. An overlap is observed among garlic samples orig- 
inating from both the Alpine and Dinaric geographical regions, whilst samples from both the Pannonian and Mediterranean regions are well separated (Fig. 3a). Overlapping results can occur due to the similar geological characteristics and climate conditions; similar findings of indistinguishable both the Alpine and Dinaric regions were also confirmed by Nečemer et al. $(2016)^{36}$ in the case with cow milk. Moreover, the Wilks $\lambda$ value ranges from 0 to 1 , indicating that means of two groups are equal if $\lambda=1$, whereas means are different if $\lambda=0 .{ }^{37}$ In our case, Wilks $\lambda$ is 0.0289 . Further, p- value $(<0.0001)$ was lower than the significance level alpha (0.1), which signify that at least one of the means vector is different from another. The discrimination among the garlic samples from the four different macro-regions is distinctly demonstrated along the Function 1 (F1) axis with $\delta^{13} \mathrm{C}$ (standardized coefficient, $-0.83), \delta^{34} \mathrm{~S}(0.64), \mathrm{Zn}(1.34)$ and $\mathrm{P}(-1.15)$. Function 2
(F2) is also linked to the variability within each particular group and the most significant parameters were $\delta^{13} \mathrm{C}$ $(-0.80)$ and $\delta^{34} \mathrm{~S}(-1.17), \mathrm{P}(0.97)$ and $\mathrm{Cl}(-1.66)$. Other parameters are less influential. F1 explains $60.48 \%$ of the total variance, while F2 accounts for $27.34 \%$. The model was validated through the leave- $10 \%$-out cross validation, which gave a success rate of $75 \%$. Additionally, the total prediction ability of leave-20\%-out and leave- $25 \%$-out was $75 \%$ and $80 \%$, respectively. In accordance with the literature data for cereals, ${ }^{9,10}$ the results confirm that $\delta^{13} \mathrm{C}$ is an important parameter for determining geographical origin. The differences in the $\delta^{13} \mathrm{C}$ values could be attributed to differences in local growth conditions e.g., temperature, relative humidity, drought stress, light intensity, and nutrient availability. ${ }^{10,38}$ Conversely, $\delta^{34} S$ is rarely used in such investigations, although sulfur isotopes in plants are known to be related to soil geology ${ }^{13}$ and are promoted as a)

Observations (axes F1 and F2: 87,8\%)

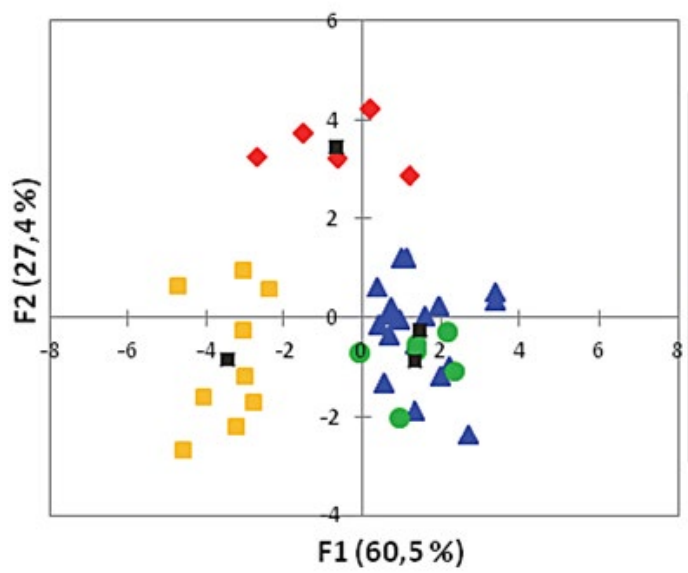

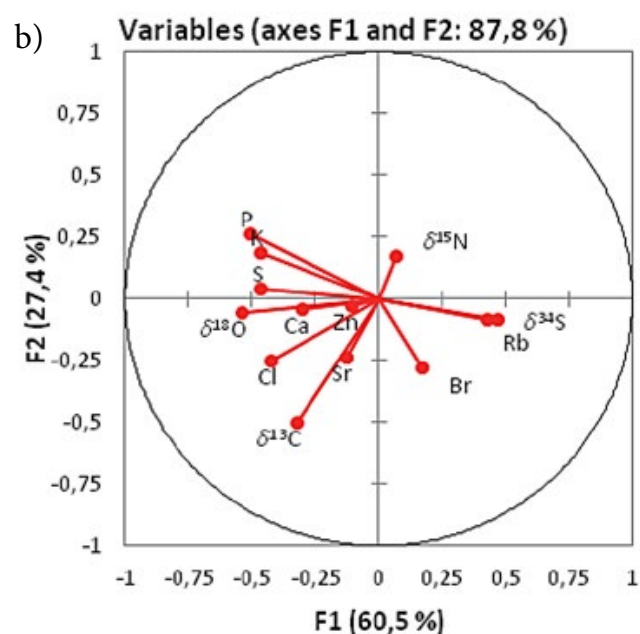

Fig. 3. (a) Discriminant score plots of 38 Slovenian garlic samples from the Alpine (A; $n=18)$, Dinaric $(D ; n=6)$, Mediterranean $(M ; n=9)$, Pannonian $(\mathrm{P} ; \mathrm{n}=5)$ regions. (b) Plot of correlations between initial variables and discriminant factors $(\mathrm{F} 1, \mathrm{~F} 2)$

a)

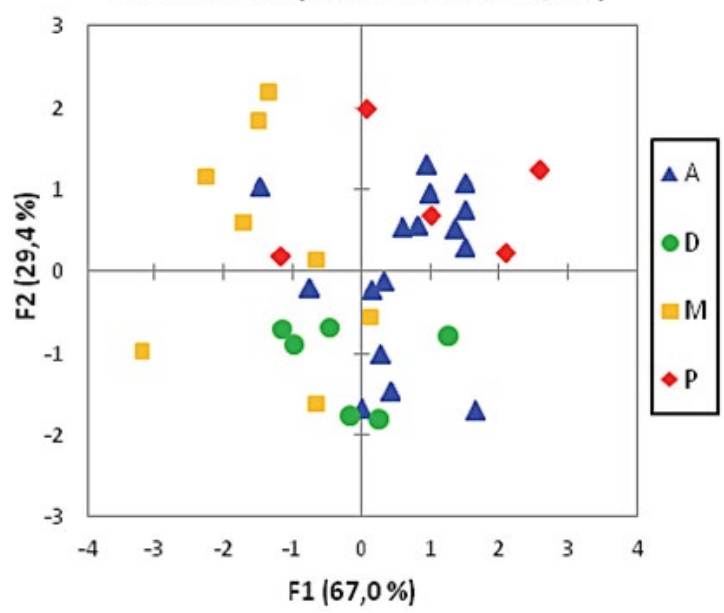

b) Observations (axes F1 and F2: 85,4\%)

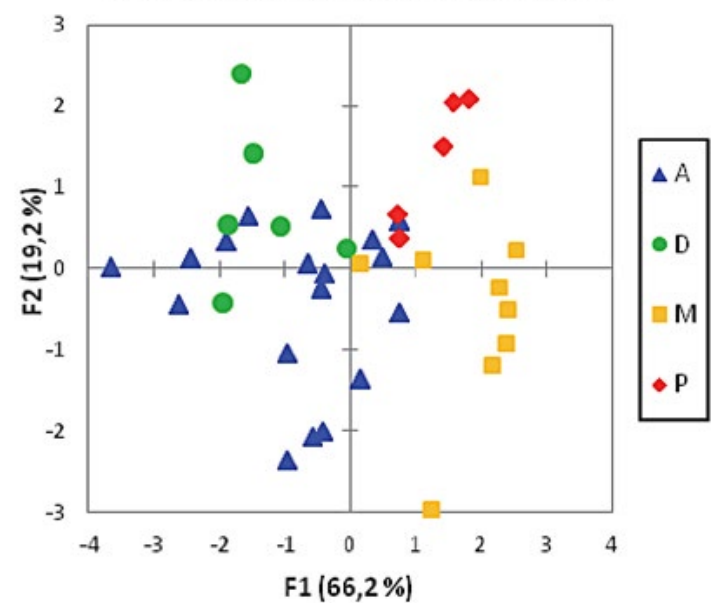

Fig. 4. Discriminant score plots of 38 Slovenian garlic samples from the Alpine $(A ; n=18)$, Dinaric $(D ; n=6)$, Mediterranean $(M ; n=9)$, Pannonian $(\mathrm{P} ; \mathrm{n}=5)$ regions applying $(\mathbf{a})$ stable isotope and $(\mathbf{b})$ elemental parameters 
valuable indicators for assigning the origin of plant material. ${ }^{39}$ Finally, the elemental fingerprint (especially $\mathrm{Zn}$ and $\mathrm{P})$ has an even greater discriminating power than the stable isotope ratios.

Directions and lengths of vectors of initial variables in Fig. 3b indicate that higher mean $\delta^{13} \mathrm{C}$ values were determined in both the Mediterranean and Dinaric regions compared to the Alpine and Pannonian. Further, the highest mean values of $\delta^{18} \mathrm{O}$ and contents of $\mathrm{K}, \mathrm{P}, \mathrm{S}, \mathrm{Cl}$ and $\mathrm{Ca}$ were measured in the Mediterranean region, but the mean $\mathrm{Rb}$ and $\delta^{34} \mathrm{~S}$ values were there the lowest. The mean $\delta^{15} \mathrm{~N}$ values were found to be the highest in the garlic samples, originated from the Pannonian region.

Additionally, in order to compare different approaches, stable isotope (Fig. 4a) and multi-elemental (Fig. $4 \mathrm{~b})$ data were tested separately. In the case of stable isotope data, the groups were not separated from each other due to overlapping results, while in the case of multi-elemental data the tendency of grouping was noticed. Nonetheless, the groups could not be distinguished according to their macro-regional origin. In first case, the major contributions to separate garlic into groups were $\delta^{13} \mathrm{C}$ and $\delta^{18} \mathrm{O}$ in $\mathrm{F} 1$ and $\delta^{13} \mathrm{C}$ and $\delta^{34} \mathrm{~S}$ in $\mathrm{F} 2$. Regarding elemental data, garlic differed mostly because of the differences in $\mathrm{P}$ and $\mathrm{Zn}$ contents in $\mathrm{F} 1$, and $\mathrm{Zn}$ and $\mathrm{Br}$ in $\mathrm{F} 2$.

\section{Conclusions}

In conclusion, the stable isotopic compositions of four elements $\left(\delta^{13} \mathrm{C}, \delta^{15} \mathrm{~N}, \delta^{34} \mathrm{~S}, \delta^{18} \mathrm{O}\right)$ and elemental composition of nine elements (K, P, S, Ca, Cl, Zn, Br, Rb, Sr) were used to differentiate the geographical origin of organically grown garlic from Slovenian certified farms. The results show a definite tendency towards their respective Slovenian macro-regions, although the slight overlap among some samples is likely due to them having been grown in regions with similar geological and climatic conditions and to the natural variability of the samples. The main parameters that differentiate the origin of the garlic samples were $\delta^{13} \mathrm{C}, \delta^{34} \mathrm{~S}, \mathrm{Zn}, \mathrm{P}$ and $\mathrm{Cl}$. Considering the results obtained, we can conclude that elemental analyser isotope ratio mass spectrometry, when combined with energy dispersive X-ray fluorescence spectrometry, has the potential to be a rapid, simple and powerful method to investigate the origin of a large number of samples. In addition, our preliminary results represented the first model of garlic in Slovenia, regarding the geographical origin of cultivation. Despite these encouraging results, there still remain some limitations and further research based on a larger dataset will be important in establishing databases that are more reliable. The annual differences in the stable isotope ratios and elemental composition of plant materials must also be taken into account, which will mean collecting samples over a number of years. Such expanded databases will require interpretations that are more complex due to the in- creased number of samples and because of the natural variation in stable isotope ratios and elemental composition.

\section{Acknowledgements}

The authors are very grateful to dr. Peter Kump for kindly providing the QAES (Quatitative Analysis of Environmental Samples) software. Many thanks also to Stojan Žigon for technical support and assistance. This study has received funding from European Union's Seventh Programme for research, technological development and demonstration under grant agreement No. 621329 (ISOFOOD ERA Chair for isotope techniques in food quality, safety and traceability), Horizon 2020 research and innovation programme under grant agreement No. 692241 (MASSTWIN - Spreading Excellence and widening participation in support of mass spectrometry and related techniques in health, the environment, and food analysis) and the Slovenian Research Agency (research programme P1-0143, Cycling of substances in the environment, mass balances, modelling of environmental processes and risk assessment).

\section{References}

1. S. G. Santhosha, P. Jamuna, S. N. Prabhavathi, Food Biosci. 2013, 3, 59-74. DOI:10.1016/j.fbio.2013.07.001

2. M. Corzo-Martınez, N. Corzo, M. Villamiel, Trends Food Sci Technol. 2007, 18, 609-625. DOI:10.1016/j.tifs.2007.07.011

3. Y. Zhao, B. Zhang, G. Chen, Food Chem. 2014, 145, 300-305. DOI:10.1016/j.foodchem.2013.08.062

4. Rules on the Quality of Vegetables, Official Gazette of the Republic of Slovenia, 86/2000, https://www.uradni-list.si/glasilo-uradni-list-rs/vsebina/2000-01-3815/pravilnik-o-kakovosti-cesna, (assessed: April 18, 2017)

5. Regulation (EC) No 2288/97, Official Journal L 315, http:// eur-lex.europa.eu/legal-content/EN/TXT/?uri=celex\%3A31997R2288, (assessed: April 18, 2017)

6. D. M. A. M. Luykx, S.M. van Ruth, Food Chem. 2008, 107, 897-911. DOI:10.1016/j.foodchem.2007.09.038

7. A. Grégrová, H. Čížková, I. Bulantová, Czech J Food Sci. 2013 , 31, 581-588.

8. M. A. Brescia, G. Di Martino, C. Guillou, F. Reniero, A. Sacco, F. Serra, Rapid Commun Mass Spectrom. 2002, 16, 2286-2290. DOI: $10.1002 / \mathrm{rcm} .860$

9. D. Luo, H. Dong, H. Luo, Y. Xian, J. Wan, X. Guo, Y. Wu, Food Chem. 2015, 174, 197-201.

DOI:10.1016/j.foodchem.2014.11.006

10. Y. Wu, D. Luo, H. Dong, J. Wan, H. Luo, Y. Xian, X. Guo, F. Qin, W. Han, L. Wang, B. Wang, Food Chem. 2015, 174, 553-557. DOI:10.1016/j.foodchem.2014.11.096

11. Y. Suzuki, Y. Chikaraishi, N.O. Ogawa, Food Chem. 2008, 109, 470-475. DOI:10.1016/j.foodchem.2007.12.063 
12. L. Zhang, J. Pan, C. Zhu, J Zhejiang Univ. 2012, 13, 824-830. DOI:10.1631/jzus.B1200046

13. A. Schellenberg, S. Chmielus, C. Schlicht, Food Chem. 2010, 121, 770-777. DOI:10.1016/j.foodchem.2009.12.082

14. K. Bizjak Bat, K. Eler, D. Mazej, B. Mozetič Vodopivec, I. Mulič, P. Kump, N. Ogrinc, Food Chem. 2016, 203, 86-94. DOI:10.1016/j.foodchem.2016.02.039

15. T. S. Pilgrim, R. J. Watling, K. Grice, Food Chem. 2010, 118, 921-926. DOI:10.1016/j.foodchem.2008.08.077

16. L. Bontempo, F. Camin F, L. Manzocco, G. Nicolini, R. Wehrens, L. Ziller, R. Larcher, Rapid Commun Mass Spectrom. 2011, 25, 899-909. DOI:10.1002/rcm.4935

17. S. V. Dutra, L. Adami, A. R. Marcon, Food Chem. 2013, 141, 2148-2153. DOI:10.1016/j.foodchem.2013.04.106

18. U. Kropf, M. Korošec, J. Bertoncelj, N. Ogrinc, M. Nečemer, P. Kump, T. Golob, Food Chem. 2010, 121, 839-846. DOI:10.1016/j.foodchem.2009.12.094

19. R. G. Smith, J Agric Food Chem. 2005, 53, 4041-4045. DOI:10.1021/jf040166+

20. I. Feher, D. A. Magdas, A. Dehelean, G. Cristea, C. Voica, Rom J Phys. 2017, 62(1-2), 803.

21. Republic of Slovenia, Statistical Office RS, SI- Stat Data Portal, http://pxweb.stat.si/pxweb/Dialog/varval.asp?lang= $2 \& m a=1502403 S \& p a t h=. . /$ Database/Okolje/15_kmetijstvo_ ribistvo/04_rastlinska_pridelava/01_15024_pridelki_povrsi$\mathrm{na} /$ \&ti $=$ (assessed: July 18, 2017).

22. Poročilo o stanju kmetijstva, živilstva, gozdarstva in ribištva, Pregled po kmetijskih trgih, http://www.kis.si/f/docs/Porocila_o_stanju_v_kmetijstvu_OEK/ZP-2015-trgi-net.pdf_(assessed: July 18, 2017).

23. D. Perko, The Regionalization of Slovenia, Geografski inštitut Antona Melika ZRC SAZU, Ljubljana, Slovenija, 2008, pp. $1-46$.

24. SIST ENV 12141:1998 (1998), Fruit and vegetable juices- Determination of the stable oxygen isotope $(18 \mathrm{O} / 16 \mathrm{O})$ of water from fruit juices- Method using isotope ratio mass spectrometry.

25. W. A. Brand, T. B.Coplen, J. Vogl, M. Rosner, T. Prohaska, Pure and Appl Chem. 2014, 86(3), 425-467.

DOI:10.1515/pac-2013-1023
26. T. B. Coplen, Y. Shrestha, Pure and Appl Chem, 2016, 88(12), 1203-1224. DOI:10.1515/pac-2016-0302

27. M. Nečemer, P. Kump, J. Ščančar, R. Jaćimović, J. Simčič, P. Pelicon, M. Budnar, Z. Jeran, P. Pongrac, M. Regvar, K. Vogel-Mikuš, Spectrochim Acta, Part B: At Spectrosc. 2008, 63, 1240-1247. DOI:10.1016/j.sab.2008.07.006

28. M. Nečemer M, P. Kump P, Vogel-Mikuš K. in: Golubev IA (Ed.): Use of X-ray fluorescence-based analytical techniques in phytoremediation, Nova Science Publishers, New York, 2010, pp. 331-358.

29. C. T. Inácio, P. M. Chalk, A. M. T. Magalhães, Crit Rev Food Sci Nutr. 2015, 55, 1206-1218.

DOI:10.1080/10408398.2012.689380

30. S. Cerar, A spatial model of underground water chemical composition in Slovenia in GIS environment, Ph.D.Thesis, Univerza v Ljubljani, Naravoslovno-tehniška fakulteta, Ljubljana, 2016, pp.

31. C. Kendall, M.G. Sklash, T.D. Bullen. in: Solute model isotope tracers of water and solute sources in catchments, Catchment Syst. J. Wiley \& Sons, New York, 1995, pp. 261-303.

32. W. G. Mook. The global cycle of water. in: Environmental isotopes in the hydrological cycle- Principles and Applications (Vol. 1), International Atomic Energy Agency and United Nations Educational, Scientific and Cultural Organization, Paris, Vienna, 2000.

33. R. Z. Chekki, A. Snoussi, I. Hamrouni, N. Bouzouita, Mediterr J Chem. 2014, 3, 947-956.

34. B. A. Akinwande, S.J. Olatunde, Int Food Researc J. 2015, 22, 332-336.

35. A. Gonzálvez, S. Armenta, M. L. Cervera, M. De La Guardia, Talanta. 2008, 74, 1085-1095.

DOI:10.1016/j.talanta.2007.09.039

36. M. Nečemer, D. Potočnik, N Ogrinc, J Food Compos Anal. 2016, 52, 16-23. DOI:10.1016/j.jfca.2016.07.002

37. F. Di Giacomo, A. Del Signore, M. Giaccio, J Agric Food Chem. 2007, 55, 860-866. DOI:10.1021/jf062690h

38. I. M. Chung, J. K. Kim, Y. I. Jin, Y. T. Oh, M. Prabakaran, K. J. Youn, S. H. Kim, Food Chem. 2016, 212, 48-57.

DOI:10.1016/j.foodchem.2016.05.161

39. N. Krivachy (Tanz), A. Rossmann, H. L. Schmidt, Food Control. 2015, 48, 143-150.

\section{Povzetek}

V tej študiji smo opisali možnost določanja geografskega porekla organsko pridelanega česna (Allium sativum L.) na področju Slovenije $\mathrm{z}$ analizo izotopske $\left(\delta^{13} \mathrm{C}, \delta^{15} \mathrm{~N}, \delta^{34} \mathrm{~S}, \delta^{18} \mathrm{O}\right)$ ter elementne $(\mathrm{P}, \mathrm{S}, \mathrm{Cl}, \mathrm{K}, \mathrm{Ca}, \mathrm{Si}, \mathrm{Zn}, \mathrm{Br}, \mathrm{Rb}, \mathrm{Sr})$ sestave. Slovenija je razmeroma majhna država (s površino le $20273 \mathrm{~km}^{2}$ ), a z vidika geološke in biološke raznolikosti zelo zanimiva za raziskovanje geografskih vplivov. Rezultate, ki so bili pridobljeni z masno spektrometrijo za analizo izotopskih razmerij in energijsko disperzijsko rentgensko fluorescenčno spektrometrijo, smo statistično ovrednotili z multivariatno diskriminantno analizo. Dobljeni model smo validirali z izpuščanjem objektov, t.j. z $10 \%, 20 \%$ in 25 \% izpuščenih objektov. V povprečju je bil odstotek pravilne klasifikacije vzorcev česna 77 \%, kar nakazuje na to, da sta model ter predlagana metodologija obetajoča za nadaljnje raziskovanje hitre, poceni in robustne kontrole porekla. 